\title{
OWEN D. GUTFREUND: 20TH-CENTURY SPRAWL - HIGHWAYS AND THE RESHAPING OF THE AMERICAN LANDSCAPE
}

\author{
(Oxford University Press, Oxford, 2004. 231 o.) \\ KESERÜ IMRE
}

Gutfreund nemrég megjelent mủve érdekes és aktuális témát feszeget, történelmi perspektívából. A szerző az egyesült államok-beli út- és autópálya-építések történetét követi nyomon egészen napjainkig, s azt vizsgálja, hogy a szövetségi kormány által támogatott közlekedési beruházások, illetve az általuk gerjesztett dekoncentráció hogyan formálta át az amerikai települések képét. A szerző tézise az, hogy a technológiai fejlődés és az emberek szemléletmódjának változása mellett az autózásnak nyújtott nyílt és bújtatott kormányzati támogatások ingatták meg a 20. század elején még erős városok helyzetét, s nagyban hozzájárultak a lakosság, a kereskedelem, a szolgáltatások és az ipar szuburbanizációjához.

A mủ hat fejezetre tagolódik. Az első fejezetben az amerikai autópálya-építések első 50 évét mutatja be általánosságban a szerző, majd három esettanulmány következik: egy nagyváros, Denver (2-3. fejezet), és két kisváros, Middlebury (4-5. fejezet), valamint Smyrna (6. fejezet). Ezek közül az európai, de talán még az amerikai olvasónak is csak Denver neve ismerős. A másik két telepullés vizsgálata arra hoz példát, hogy az autópálya-építések nemcsak a nagyvárosok környékét, hanem a kisvárosokat is átalakították.

Már a bevezető fejezet (,Autópálya föderalizmus”) rávilágít arra az egész müvön végigvonuló felismerésre, hogy az amerikai autópálya-építések kezdetétöl mutatkozott egyfajta, az autós lobbi által táplált város-ellenesség a központi kormányzat részéröl. Politikai okokból (a döntően „vidéki” államok sikeres lobbizásának köszönhetöen) már az elsö útépítésre adott szövetségi támogatások is a vidéki, termelőktôl piacra vezetô, illetve a vidéki települések postai ellátását segítỏ utakat részesítették előnyben; később pedig a regionális összeköttetések fejlesztése került elötérbe, miközben a városi utak építésére és felújítására kevés pénz jutott. A másik fontos elem, ami végigvonul a könyvön, hogy az autózás költségeit (útépítések, útfenntartás, adminisztráció) rendre nem fizettették meg a használókkal, így az autózást közvetve az állam támogatta, ami egybevágott az autógyártók érdekeivel. Mindez összekapcsolódva a szuburbanizációt segítő lakáspolitikával és az adórendszerrel a dekoncentráció irányába hatott. Ezeket az általános megállapításokat az esettanulmányok illusztrálják.

Denverben a téma irodalmából jól ismert módon alakult át a városszerkezet: a belváros az 1970-es évekre elnéptelenedett, az elỏvárosok ezzel szemben rohamos ütemben fejlődtek. Ezt a változást igen nagy részben az autópálya-hálózat kiépíté- 
sével és a tömegközlekedési hálózat leépítésével indokolja a szerző. Szemléletes példa, hogy Denver egyik elővárosa, Aurora 1950-ben még csak 11000 lakossal rendelkezett, míg 1990-ben már 220000 lakosa volt, igen nagy részben a közelben felépült két autópálya és az új nemzetközi repülőtér hatására. Ezzel az egykori elöváros lakosságszámban a központi város, Denver riválisává vált. Mindeközben az egykor virágzó denveri belvárost csak nagy erőfeszítések és anyagi áldozatok árán sikerült rehabilitálni.

Middlebury esete azt illusztrálja, hogy a dekoncentráció következtében megnövekvö forgalom, s a forgalom növekedését nem követő útfejlesztések miatt hogyan alakult ki már a múlt század közepére a közlekedési káosz ebben a mindössze 8000 lelkes kisvárosban. Már több mint 50 éve megszülettek a tervek a jelenleg a városon keresztülhaladó forgalmas foút elkerülö szakaszának megépítésére, illetve egy új hídra, ami a városkát átszelő folyón teremtene második átkelési lehetőséget. Az autópálya-építéseket támogató szövetségi politika miatt azonban eddig nem volt pénz a fejlesztések megvalósítására. Middlebury példája nem egészen illeszkedik a tanulmány koncepciójához, hiszen a dekoncentrációban itt nem volt szerepe az autópálya-fejlesztéseknek. A kisváros inkább annak illusztrálására alkalmas, hogy az autózást támogató politika és az autózás alacsony költségei univerzálisan, tehát az egész ország területén dekoncentrációhoz vezettek, legyen szó akár egy nagyvárosról, mint Denver, akár egy kisvárosról, mint Middlebury.

A harmadik példa, Smyrna szintén jelentéktelen kisváros volt jó darabig. Majd a második világháború idején katonai légibázis nyílt, ami fellendülést és jelentős infrastruktúra-fejlesztéseket hozott. A bázis 1970-es bezárása sokkhatásszerüen érte a település gazdaságát, később a légikikötő azonban a fejlődés egyik motorjává vált regionális teherforgalmi repülötérként. A fejlödés másik fontos hajtóereje lett a közelben megépült I-24 autópálya, majd annak leágazásai. Ma a település három fontos országos útvonal keresztezödésében fekszik. A kedvezó közlekedés-földrajzi helyzet vonzotta a településre a japán Nissan céget, itt építették fel Észak-Amerika legnagyobb autógyárát. A gyár felépülése után gombamód szaporodtak az egyéb ipari és kereskedelmi vállalakozások is. A település lakossága az 1970-es 5698 föröl 2000-re 25769 före nőtt, a kereskedelmi létesítmények kitelepültek a város szélére az autópálya mellé, és új lakóterületeket alakítottak ki szintén az autópályák könnyü elérhetőségét tartva szem elött. A belvárosi kereskedelmi negyed csak a turistaforgalomra való átállással menekülhetett meg az enyészettől. Kicsiben, de lejátszódott mindaz, ami az amerikai nagyvárosokban. A szerző következtetése: a vidéki Amerikában a hagyományos nagyvárosok rovására véghezvitt nagy állami infrastruktúra-fejlesztések a Smyrnához hasonló kisvárosok gyors fejlödését és dekoncentrációját tették lehetỏvé.

A fenti három példa alapján a szerző arra a következtetésre jut, hogy az amerikai dekoncentráció fỏ okai a következök voltak: az autós lobbi (autógyártók, olajtársaságok, útépítők, tervezők) által hangoztatott, s az amerikai közgondolkozásba ültetett „,Szabadságjog", a szabad autóhasználat eszméjének elterjedése; a közutak használatában nem alakult ki a „használó fizet elv”, az autópályák többségében ingyenesek, 
s állami pénzből épülnek; az autóhasználat alulárazása miatt a kereslet-kínálat (utazási igények - meglévő utak) egyensúlya felbomlott, s erre nem az egyensúly helyreállításával válaszoltak, hanem még több útépítéssel; emellett az útépítéseknél rendre hátrányban voltak a városok. Mindezek természetesen önmagukban még nem lehetnének okai a szuburbanizációnak. Kellett hozzá az is, hogy az amerikai gondolkodásmódban megerỏsödjön az önál ló ház igénye, hogy a kormányzat lakás- és adópolitikája a zöldmezös beruházásokat támogassa, hogy nőjön a lakosság életszínvonala, valamint a befektetök érdekei is az elővárosi fejlödés irányába hassanak.

Összegzésként a szerző felidézi az 1939-es New York-i világkiállítás General Motors (GM) által készített Futurama nevű kiállítását, amely egy, a GM által elképzelt világba röpítette el a látogatókat. Az autógyártó úgy képzelte el a szép új világot, hogy az emberek $2 \times 7$ sávos autópályákon akadály nélkül $160 \mathrm{~km} /$ óra sebességgel közlekednek. A kapcsolódó Democracity nevü kiállítás a jövő városát mutatta be, ahol senki sem él többé a központi városban, hanem a $17600 \mathrm{~km}^{2}$-nyi területen élő 1,5 millió lakos a várost köruilvevő elövárosokból ingázik széles autópályákon. Tömegközlekedés nem létezik, de érdekes módon légszennyezés sem. Mindkét álom - ha nem is teljesen így - valóra vált, a következmények azonban mélyrehatóak: a $160 \mathrm{~km} / \mathrm{h}$ sebesség helyett állandósultak a forgalmi dugók, $\mathrm{s}$ a közlekedési eredetű légszennyezés miatt például Denverben rendszeressé váltak a szmogriadók.

Gutfreund munkájában keveredik a város-, politika- és közlekedéstörténet, valamint a városföldrajz. Maga a szerző nem földrajzkutató: történelmet tanít a New York-i Barnard College-ben és az Urban Studies Program vezetöje a Columbia Egyetemen. A könyv ennek ellenére érdekes és értékes háttérinformációkat ad az amerikai szuburbanizáció kutatásához. A könyvben részletesen leírt esettanulmányok segítenek megérteni, hogy a hibás terület- és településfejlesztési elgondolások, illetve a befektetők és a beruházók túl nagy beleszólása a fejlesztésekbe milyen következményekkel jár. A mü végkicsengése meglehetösen pesszimista, a dekoncentráció folytatódásával számol. A munka elsődlegesen leíró jellegü, így nem is próbál kiutat mutatni a közlekedési és tervezési válságból.

A könyv számos olyan dologra is felhívja a figyelmet, amelyek a magyarországi terület- és közlekedésfejlesztésben is megszívlelendők. Az autópályadíjak kérdésében például az amerikai példák azt mutatják, hogy az ingyenes autópályák a szuburbán övezetek gyorsabb növekedését segítik, miközben társadalmilag is igazságtalanok az autópályát nem használókkal szemben. Az autózás költségeinek társadalomra hárítása Európában is probléma, ha nem is olyan nagy, mint az USAban. S ebböl a szempontból nem csak az útépítés és fenntartás, hanem a környezetszennyezés és a balesetek által okozott károkat is számításba kell venni. A városi utak és a parkolás fejlesztésének elhanyagolása is az autópályák menti elövárosok megerösödését segíti, amelyek könnyen elérhetök, és szabad területek is nagy számban állnak rendelkezésre ingyenes autóparkolók létesítésére.

Érdekes, s a magyar tervezők számára is elgondolkodtató, hogy a távolsági forgalom számára tervezett autópályákon a forgalom a megnyitás után rövid idővel meg- 
haladta az elöre jelzettet, $\mathrm{s}$ a növekedés elsősorban a városkörnyéki utazásokból adódott. Hasonló a probléma a Budapest körüli M0 autóúttal is, hiszen az eredetileg föleg a tranzitforgalom elvezetésére épített út forgalma elsősorban a városkörnyéki forgalom jelentős növekedése miatt hamar meghaladta az elöre jelzettet és az út kapacitását.

Tanulság lehet még számunkra, hogy a helyi, települési utak építésénekfelújításának támogatása is nagyon fontos, nem csak az eröltetett autópálya-építési program. Budapesten is tipikus probléma, hogy a városba bevezető autópályák a városba érve szủk keresztmetszetủ utakban folytatódnak. Ha a forgalom elkerüli a várost, előbb utóbb és egyre nagyobb mértékben a tevékenységek is követik azt a városon kívülre, amint azt az utóbbi 10 év is mutatta.

Ajánlom a könyvet a szuburbanizáció gyökerei iránt érdeklődőknek, a tervezőknek (hogy lássák, mit kellene elkerülni), de azoknak is, akiket érdekel a közúti közlekedés történetének egy mozgalmas és érdekes szelete. 